\title{
BIM Based Time Management Among Construction Contractors in Turkey
}

\author{
An Interview Study
}

\author{
Ayşen Saraç Çıracıoğlu ${ }^{1 *}$, Hakan Yaman \\ ${ }^{1}$ Department of Architecture, Faculty of Architecture, Istanbul Technical University, 34367 Şişli, Istanbul, 2 Taşkışla Street, Turkey \\ *Corresponding author, e-mail: saraca@itu.edu.tr
}

Received: 24 January 2021, Accepted: 02 November 2021, Published online: 14 December 2021

\begin{abstract}
In both developing and industrialised countries, due to numerous time-related problems of construction projects, BIM-based time management, 4D BIM, plays an increasingly critical role within the industry. This study investigates the planning and scheduling problems, BIM application level, and BIM-based scheduling implementation by the lead construction companies in Turkey.

Despite the critical importance of the planning department in construction companies, the planning and BIM integration levels have scarcely been investigated from the contractor perspective in Turkey.

This paper presents the outcomes of 16 semi-structured interviews (SSI) with managers of the leading Turkish contractors selected from 100 of ENR's 2019 Top 250 International Contractors list; a list of issues are outlined. The current situation escalates problems like tendering with missing project documents, examining 2D project drawings while scheduling, fragmentation, project manager's reluctance to use and follow the project schedule, issues with updating the schedule as per construction improvements and quantities, and a lack of investment for BIM implementation. The research findings, ultimately, aim to help contractors improve their processes. Although this study's findings are obtained from interviews with lead Turkish contractors, it is not limited in terms of geographic context since the interviewed contractors work worldwide.
\end{abstract}

Keywords

BIM, 4D, time management, construction, Turkey

\section{Introduction}

The project planning and scheduling process is key to successful project management (Pellerin and Perrier, 2019). It plays a significant role in determining the available resources' flexibility and guarantees that tasks are completed logically and timely. However, although the planning and scheduling process becomes a substantial challenge for contractor companies, it still relies on traditional methods, and many project failures exist related to it (Derbe et al., 2020). Moreover, late project completion commonly has undesirable effects on contractor companies, such as penalty costs and customer dissatisfaction (Sahu and Sahu, 2014). Therefore, practitioners' increased emphasis on the planning process contributes to developing a diligent and efficient project planning and scheduling process (Lekshmi and Unnikrishnan, 2018).

At present, contractor companies face many problems due to traditional planning and scheduling process- es (Faghihi et al., 2014; Sacks et al., 2010; Navon and Sacks, 2007; Sarhan and Fox, 2013). The problems are identified as follows: insufficient information provided by 2D diagrams or charts (Koo and Fischer, 2000; Faghihi et al., 2015), lack of visualisation, an inefficient collaboration between stakeholders (Gledson, 2015); inability to model risk (Mongalo and Lee, 1990; Yang, 2005), high dependency on the planners' ability, the gap between master and detailed schedule (Mahalingam et al., 2010; Candelario-Garrido et al., 2017), identifying and reporting the status of the project, comparing it with the master plan, analysing the deviations, detecting out-of-control situations, and taking appropriate corrective actions (Hazir, 2015). Furthermore, the critical path method (CPM) and bar charts, as one of the traditional planning tools, criticised as not detecting design errors and design mismatches (Li et al., 2008), challenging to use and update (Huber and Reiser, 2003), and hard to 
manage (Waly and Thabet, 2003), can easily cause schedule inconsistencies. Also, CPM has no resource utilisation capabilities (Lu and Li, 2003; Zhang et al., 2006) and cannot provide spatial features for resources and working spaces.

BIM has a fundamental role in providing clarity and availability of information, especially in the face of the complexity of construction projects (Dave et al., 2013; Tezel et al., 2016; Walker, 2015), both in terms of structural complexity and uncertainty (Li and Williams, 2002; Tjell and BoschSijtsema, 2015). Research studies and literature indicate that project planning and scheduling is much more efficient in the 4D environment than in traditional planning (Aredah et al., 2019; Candelario-Garrido et al., 2017; Han and Golparvar; 2015; Olde Scholtenhuis et al., 2016; Kassem et al., 2015; Wang et al., 2004; Kim et al., 2013a). BIM can constitute the planning process by improving communication and collaboration among project stakeholders, process transparency, effective decision making, obtaining reliable information flow, identifying spatial conflicts in construction, and assessing project constructability. Further, 4D technology specifically solves the visualisation and time-related issues where the traditional methods suffer most. Recently, researchers have been focusing on emerging technologies such as four-dimensional building information modelling (4D-BIM). 4D BIM incorporates project time-related information to the $3 \mathrm{D}$ information model to simulate the sequence of construction operations (Allen and Smallwood, 2008; Büchmann-Slorup and Andersson, 2010; Gledson and Greenwood, 2017; Mahalingam et al., 2010; Li et al., 2015; Trebbe et al., 2015).

This paper aims to analyse the planning and scheduling problems, BIM application level, and the BIM and schedule integration level of the construction companies in Turkey. For this purpose, semi-structured interviews were carried out with 16 professionals working in the seven lead Turkish contractors ranked in the first 100 of the ENR 2019 Top 250 International Contractors (Engineering News-Record, 2019). This study is not limited in terms of geographic context since those contractors work all around the world. This study's findings are expected to be helpful for contractors to improve their planning and scheduling processes and practices. Further, the study can provide new insights for contractors using or planning to use BIM-based scheduling applications.

\section{Background}

In the traditional construction process, planning has been widely examined due to its impact on performance during the execution phase. However, in construction, the focus has been on developing planning tools rather than on the theoretical issues promoting its improvement (Laufer et al., 1994). This has resulted in inadequately managed projects and poor performance (Ballard, 2000; Koskela, 2000). Gonzalez et al. (2010) identified poor planning, rather than unforeseeable events, as the most significant contributor to poor time performance.

BIM process is a good asset in the project design stage and the subsequent construction stage, provided it ensures working effectiveness and time saving along the project life cycle (Eadie et al., 2013). Further, a vital benefit of the introduction of BIM is its use in project planning. "4D BIM" is acknowledged as a valuable addition to construction planning methods as it produces construction process-visualisations (Hartmann and Vossebeld, 2013), which enable better understanding (Heesom and Mahdjoubi, 2004; Wang et al., 2004) and decision-making (Hartmann et al., 2008). Further, 4D BIM simplifies construction activities' time and space relationships and supports multi-party information sharing that is beneficial to project management (Gong et al., 2019).

Koo and Fischer (2000) analysed 4D planning viability through a case study. They concluded that 4D models enable users to quickly understand a schedule and identify potential problems, which is a valuable alternative to project scheduling tools like CPM networks and bar charts. In the same line of research, Heesom and Mahdjoubi (2004) proposed a model to determine the usage requirements for each of the various applications of 4D CAD simulations. Finally, Jongeling and Olofsson (2007) presented a process method for the planning workflow by combining location-based scheduling and 4D CAD. They suggested that a location-based approach to 4D CAD might improve the model's usability for workflow analyses.

Moon et al. (2014) applied the 4D system to the case study to identify the project conflicts. They discussed practical applications and feasibility of the system and verified that a 4D analysis system could improve the results of a project. Aredah et al. (2019) distributed an online electronic questionnaire worldwide to measure the effects of 4D BIM on the construction industry. According to the survey analysis, more than $75 \%$ of the total respondents agreed that 4D BIM is superior to traditional scheduling techniques; communicating the plan, sequence assessment, and gathering information have been the most rated aspects compared to traditional planning. Other planning-related benefits of 4D BIM include more effective coordination 
and review practices (Hartmann and Fischer, 2007; Olde Scholtenhuis et al., 2016), better planning and management of on-site space and resources (Kassem et al., 2015; Wang et al., 2004), use of automated construction progress tracking capabilities (Kim et al.,. 2013a; Kim et al., 2013b) and iterative studies of the schedule (Tulke and Hanff, 2007). For implementing 4D BIM, the most significant constraints are still seen as the cost, contractual pressure, and a lack of understanding of how the technology will be applied. However, the Standish Group 2015 Chaos Report pointed out that any successful project which used a 4D tool in their process met the planned time, budget and increased productivity. Also, the Centre for Integrated Facility Engineering confirmed that 4D modelling at the appropriate stages in the construction process results in significant building efficiencies and cost savings (Zhang et al., 2018).

Although the construction sector has an essential role in the Turkish economy, it has been found that the Turkish construction sector faces delay problems (Arditi et al., 1985; Kazaz et al., 2012). In 2012, Kazaz et al. (2012) examined the factors causing delays in the Turkish construction industry with 71 Turkish contractor companies through mutual interviews and questionnaires, based on 34 factors they compiled from the literature review. Ignoring modern planning techniques and still using traditional methods have been shown as fundamental causes of financial crises in the sector and delays in the work schedule. As a solution, it has been suggested to use modern project management techniques to allocate sufficient financial resources to the projects and manage projects with skilled technical personnel with sufficient experience.

In 2008, face-to-face meetings were held with 26 contractors to determine the planning perceptions in the Turkish construction sector. Primary deficiencies were identified as controlling the schedule, monitoring it with information flow, and revising the schedule when necessary (Ugur and Baykan, 2008). According to a survey conducted on the applicability of 4D modelling in the Turkish construction sector in 2014, it was found that 4D modelling was not widely used in the Turkish construction sector (Gokyigit, 2014). The literature review shows that the Turkish construction industry is heavily fed by traditional planning and scheduling processes and struggles with delayed project deliveries and inefficient workflows. Furthermore, studies on BIM-based time management in the Turkish construction sector are limited, and further investigation is needed to clarify the current situation.

As can be seen, numerous studies have been performed to reveal the importance of BIM for planning and scheduling practice and the traditional planning process's problems. However, none of these studies presents the current planning and scheduling practices and the BIM integration level in internationally competitive contractor firms. Therefore, this study is arguably the first one of the in-depth studies investigating the problems encountered during the planning and scheduling process and the current use of BIM-based schedules (4D BIM) in internationally competitive contractor firms. Additionally, it is thought that studies have contributed to both theory and practice by identifying and introducing the most important factors for the planning and scheduling process and BIM integration.

\section{Research methodology}

\subsection{Method design and data collection}

Due to its exploratory nature, the qualitative method is employed in this study. BIM and planning process integration concepts are new to professionals, and the subject is rarely studied and reported in the Turkish construction industry. Yin (2009) pointed out that qualitative methods are more appropriate for studying new phenomena than quantitative methods because they better explain how and why. Moreover, qualitative research enables us to understand how the 4D BIM concept is being used in Turkey. However, it requires a long time to accomplish (Jacobs, 2010).

A literature review was designed to provide clear insight into and understand relevant research practices in the planning processes. The literature review has provided an overview of different planning and scheduling techniques and the benefits of 4D BIM implementation worldwide. It also helped restructure the interview questions around the issues such as the effect of planning method on the project cost overruns and delays, the relation of schedule variability and productivity, the effect of current planning methods on the management and communication of field teams. In addition, the BIM incorporation level in the planning process was not explicitly addressed in the previous research.

There are two primary purposes of the interviews carried out in this study:

1. To investigate the current planning methods adopted by construction professionals and determine the problems encountered during the planning and scheduling process.

2. To identify the level of BIM usage in the planning and scheduling process and to understand the contractors' approach and hence benefit from BIM.

Semi-structured interviews (SSI) were conducted with 16 professionals who manage the planning and BIM 
departments of the seven leading Turkish constructors in the 100 of ENR's 2019 Top 250 International Contractors list (Engineering News-Record, 2019). These companies construct malls, offices, hotels, residences, healthcare complexes, airports, heavy industry plants, and embassy buildings. Moreover, they have a $4.6 \%$ share in the global market with revenues of 21.6 billion USD (Engineering News-Record,2019). They serve as the main contractor in a wide area spanning Central Asia, Europe, the Middle East, Africa, Russian Federation, and Turkey. One of the companies interviewed maintains its leading position among Turkish contractors with a turnover of 5.4 billion USD across 28 countries, ranks $9^{\text {th }}$ in Europe and $23^{\text {rd }}$ in the list of the world's largest construction companies (Engineering News-Record, 2019). The rest of the companies have an average of more than 3 billion USD as annual turnover. (Turkish Contractors Association).

Moreover, one was ranked number 1 globally in airport construction in 2018 (Engineering News-Record, 2019). One of the referred projects of the interviewed company has an approximate residential area of 120,395,833 square meters, and the approximate construction area is 325,000 square meters. It is evident that these contractor companies build large scale international projects and are competitive worldwide.

\subsection{Interview}

The interviews were semi-structured with open-ended questions. Open-ended questions were preferred in order not to limit the respondents. In semi-structured interviews, researchers have the opportunity to collect more in-depth data on a subject matter than survey studies. Unlike questionnaire surveys, where the rigid nature of the questions restricts the respondents, the semi-structured interview process is flexible. Moreover, they can reveal rich insights for exploratory research and support the evaluation of complex topics by providing rich and complete data (Rapley, 2001; Berg, 2004; Easterby-Smith et al., 2008). In addition, interviews allow researchers to control the response environment, control the order in which issues are discussed, and learn about things that can be observed only with difficulty. They are most approached in exploratory research (Churchill and Brown, 2002). Bryman (2012) stated that a semi-structured interview is commonly used to promote standardisation when asking and recording responses to the interview questions.

Since 4D BIM is still rare in Turkish construction, the appropriate persons to interview were identified by searching the lead Turkish contractor companies. In this sense, the top 100 of the ENR 2019 list is used. There are seven Turkish contractors on the list, and all of them responded to the interview request positively. The 16 respondents working in these companies consisted of nine planning professionals and seven BIM experts and were interviewed face-toface for 45-90 minutes between May 2019 to December 2019. Face-to-face interviews were preferred in this study due to their high response rate; However, the respondents were usually reluctant to allocate enough time to answer all the open-ended questions during the interviews. Some $69 \%$ of the respondents were civil engineers, while $31 \%$ of them were architects. More than $90 \%$ of the nine planning professionals have planned at least three international construction projects, and $50 \%$ of the BIM experts have experienced the $4 \mathrm{D}$ process. The average length of experience of the respondents was 15 years, and the professional background and qualifications of the respondents are sufficient for the validation of the interview results. The profile of the interviewees is shown in Table 1.

The interview consisted of three sections. The first section was about the context and the organisational structure of the respondent company. The second section comprised the questions to determine the major problems encountered in creating and implementing the construction schedule, the actions taken in case of deficiencies, and the planning culture of the firms. The third section comprised questions regarding BIM implementation and the application level of BIM technology in the planning process. The interview questions are seen in Table 2. The order of the questions varied between the interviews, as some questions related to the planning process were only answered by planning professionals $(n=9)$. Also, some questions regarding the BIM process were just answered by BIM experts $(n=7)$. Since the interview was held with open-ended questions, the respondents' similar answers were grouped, and the frequency of each answer was calculated. Simple descriptive statistics such as percentages were used in analysing the interviewed data. Descriptive statistics summarise and organise characteristics of a data set. A data set is a collection of responses or observations from a sample or entire population.

\section{Findings}

Based on the semi-structured interviews, to precisely explain the source of the main problem areas among the different planning stages, findings are grouped as tendering process and the implementation of construction 
Table 1 Profile of the interviewees

\begin{tabular}{lcc}
\hline Company name & Role of the interviewee & Year of experience \\
\hline Company A & Planning Chief/ Civil Engineer & $>15$ \\
Company A & Planning Chief / Civil Engineer & $>5,<10$ \\
Company B & Cost and Procurement Manager/ Civil Engineer & $>15$ \\
Company B & BIM Supervisor/ Civil Engineer & $>10$ \\
Company C & Planning and Cost Manager/ Civil Engineer & $>10$ \\
Company D & Planning and Cost Manager/ Civil Engineer & $>10$ \\
Company E & BIM Manager/Architect & $>15$ \\
Company F & Design Manager/Architect & $>5,<10$ \\
Company F & Technical Office Manager/ Civil Engineer & $>15$ \\
Company F & Planning Manager/ Civil Engineer & $>10$ \\
Company G & BIM Manager/Architect & $>10$ \\
Company H & BIM Manager/ Architect & $>10$ \\
Company I & Information Technology Manager/ Civil Engineer & $>10$ \\
Company I & Construction and Design Manager/ Civil Engineer & $>15$ \\
Company J & Planning Manager/ Civil Engineer & $>10$ \\
Company L & BIM Supervisor/Architect & $>5,<10$ \\
\hline
\end{tabular}

Table 2 Interview questions

\begin{tabular}{|c|c|}
\hline Q1 & What is your job description and years of experience in the company? \\
\hline Q2 & What are the types and sizes of projects carried out by the company? \\
\hline Q3 & $\begin{array}{l}\text { What methods and techniques are currently used in the planning process? What is the effect of it on the risk } \\
\text { and uncertainty issues of the projects? }\end{array}$ \\
\hline Q4 & What are the previously used planning techniques and methods? \\
\hline Q5 & $\begin{array}{c}\text { Based on your experience, what are the barriers you have observed from implementing the planning process } \\
\text { from starting early project phases? }\end{array}$ \\
\hline Q6 & $\begin{array}{c}\text { Based on the planning methods and techniques you use, what are the problems, deficiencies, and mistakes that } \\
\text { you encounter most frequently and that affect you the most? }\end{array}$ \\
\hline Q7 & What do you suggest should be done to solve the problems encountered in the planning phase? \\
\hline Q8 & What is the effect of the planning process on time and cost increases in projects? \\
\hline Q9 & Are the necessary construction methodologies for implementation determined in the planning process? \\
\hline Q10 & $\begin{array}{c}\text { At what stage in the planning phase are negotiated with project stakeholders? How is the work sequence and } \\
\text { order created? }\end{array}$ \\
\hline Q11 & What is the impact of currently used planning methods on the management and communication of field teams? \\
\hline Q12 & What kind of problems site team encounter in the implementation of the construction schedule? \\
\hline Q13 & How are coordination and communication between teams provided as of the beginning of the planning process? \\
\hline Q14 & Do project managers effectively follow overall schedules in the field? \\
\hline Q15 & $\begin{array}{c}\text { How are the monitoring and control stages of the work program currently carried out? What are the problems } \\
\text { experienced during the control? }\end{array}$ \\
\hline Q16 & $\begin{array}{l}\text { Does the company implement BIM technology? If yes, which BIM tools are used for which purpose? Do you } \\
\text { face any problems while using BIM tools? }\end{array}$ \\
\hline Q17 & Does the company have a BIM team in the head office or construction sites? \\
\hline Q18 & Do you have a BIM execution plan or follow any BIM standards? \\
\hline Q19 & $\begin{array}{c}\text { Do you follow BIM based-planning approach? Have you ever experienced 4D BIM in projects? If yes, which } \\
\text { tools do you prefer? }\end{array}$ \\
\hline
\end{tabular}

schedules process. Moreover, with this classification, the suggested measures taken for the lacking areas are intended to be better determined. In addition, to shed light on the BIM adaptation process of leading Turkish 
contractors, findings are presented under three headings: BIM team structure, the current level of BIM, and schedule integration and encountered problems while implementing BIM tools. With the help of this grouping, the aim is to highlight the processes which require improvements to achieve BIM and schedule integration.

\subsection{Major problems encountered during tendering processes}

In this section, while calculating the response rate, data analysis was based on the responses of nine planning professionals, which represented a response rate of $100 \%$.

Responses to Q5 showed that due to the incompleteness of the design documents $(100 \% ; n=9)$, the contractors face uncertainties in the construction phase. Also, most interviewers agreed that $2 \mathrm{D}$ coming projects from design firms $(88.9 \% ; n=8)$ are another big challenge for the planners while examining the project and working on quantity take-offs. In particular, it is learned that inaccurate information from $2 \mathrm{D}$ drawings causes a high level of quantity take-off (QTO) errors $(66.8 \% ; n=6)$. Moreover, most owners schedule a short time for the tendering process $(100 \% ; n=9)$, and contractors do not have adequate time to examine the project and estimation. Accordingly, they do not go to the construction site to analyse the current situation of the project area $(66.7 \% ; n=6)$. Thus, planners prepare bidding documents depending on past experiences, and they miss the project-specific conditions. In Q8, lack of workers productivity analysis in international jobs $(77.8 \% ; n=7)$ is another problem while estimating since it causes cost overruns and delays in the project.

Responses to Q3 and Q4 revealed that the Critical Path Method (CPM) is the most used technique with $(100 \%$; $\mathrm{n}=9$ ) followed by Program Evaluation and Review Technique (PERT) and TILOS with percentages fluctuating around $22.3 \%(\mathrm{n}=2)$. Although CPM is highlighted regarding the ease and superiority in dealing with complex projects, in Q6, some respondents criticised it as not allowing them to try different scheduling scenarios $(33.4 \% ; n=3)$, which is a kind of software problem.

Also, Q10 and Q13 revealed a coordination and communication problem $(44.4 \% ; n=4)$ among the team in the tendering stage. Therefore, the overall scheduling process should be prioritised and coordinated with stakeholders' commitments $(66.8 \% ; n=6)$ in the early phases of the project, which is vital to promote the transfer of knowledge and information flow between the overall and the detailed schedule (Büchmann-Slorup and Andersson, 2010).
Fig. 1 presents the significant problems that contractors suffer in the tendering stage. They cause a considerable gap between the overall and the detailed schedule.

\subsection{The problems encountered in the implementation of the construction schedule}

In this section, while calculating the response rate, data analysis was based on responses of nine planning professionals, which represented a response rate of $100 \%$.

Response to Q12 showed that the site staff mostly use the $2 \mathrm{D}$ drawings to examine and follow-up projects, which causes them to lose time and not see clashes and conflicts quickly $(100 \% ; n=9)$. Another important problem pertains to quantity take-off errors (QTO) $(100 \% ; n=9)$, which causes significant project cost and time problems. If the site team uses BIM models in place of 2D drawings, they would have the opportunity to extract quantity take-offs from the BIM model automatically.

The biggest challenge in any planning and control system in construction sites is ensuring consistency across different decision-making layers (Harris and McCaffer, 2013; Kerzner, 2013). In Q14, the project managers' unwillingness to use the construction schedule has been another significant problem $(100 \% ; n=9)$. It is learned that project managers tend to change construction priorities and reorganise the schedule mostly without coordinating with the other team members. This is because project managers are rarely involved in the overall schedule phase. Significant changes in the schedule and workflow require other teams to adapt and reconfigure their priorities. Unfortunately,

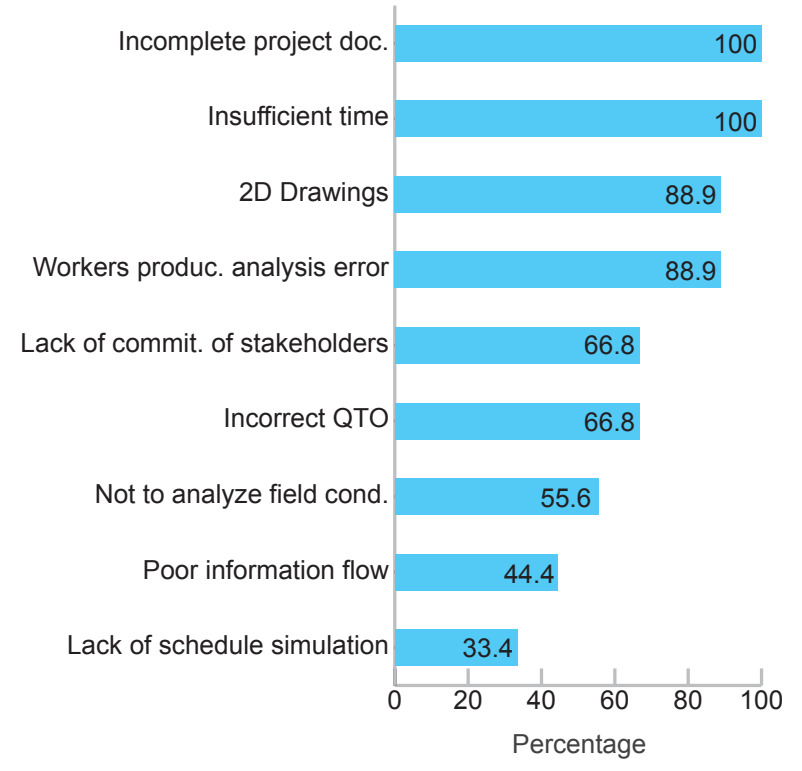

Fig. 1 Major problems that contractors suffer during tendering processes 
those changes usually result in conflicts in cost, time, and coordination problems among team members.

In Q11, the participants pointed out that the currently used planning method and excel spreadsheets are unsuitable for exchanging information and communicating between the actors to develop an efficient schedule $(55.6 \% ; \mathrm{n}=5)$.

Responses to Q15 revealed an uncoordinated schedule with the QTO tracking $(100 \%$; $=9)$ and incorrect information sharing during field monitoring $(100 \% ; n=9)$, which generally causes cost overruns. Also, in Q7, respondents pointed out a requirement for additional staff at the field planning department $(77.8 \% ; n=7)$. The current planning team in the field is usually not sufficient to follow up schedules in detail. Moreover, in some cases, the materials sent to the field are used in the wrong places $(66.8 \%$; $n=6)$, which is not reflected in the schedules.

Fig. 2 present the significant problems that contractors suffer, while implementing the construction schedules.

\subsection{BIM team structure of the interviewed companies}

In this section, while calculating the rate for the responses, data analysis was based on the responses of 7 BIM experts, which represented a response rate of $100 \%$.

The BIM concept was proposed to the construction industry to improve efficiency, lower costs, and overall management benefits during all stages of construction (Succar, 2009).

Interviews revealed that (responses to Q17) most contractors $(85.7 \% ; \mathrm{n}=6)$ have a BIM team in the construction sites. 3D coordination, clash detection, and visualisation are found as the main BIM benefits. However, the BIM

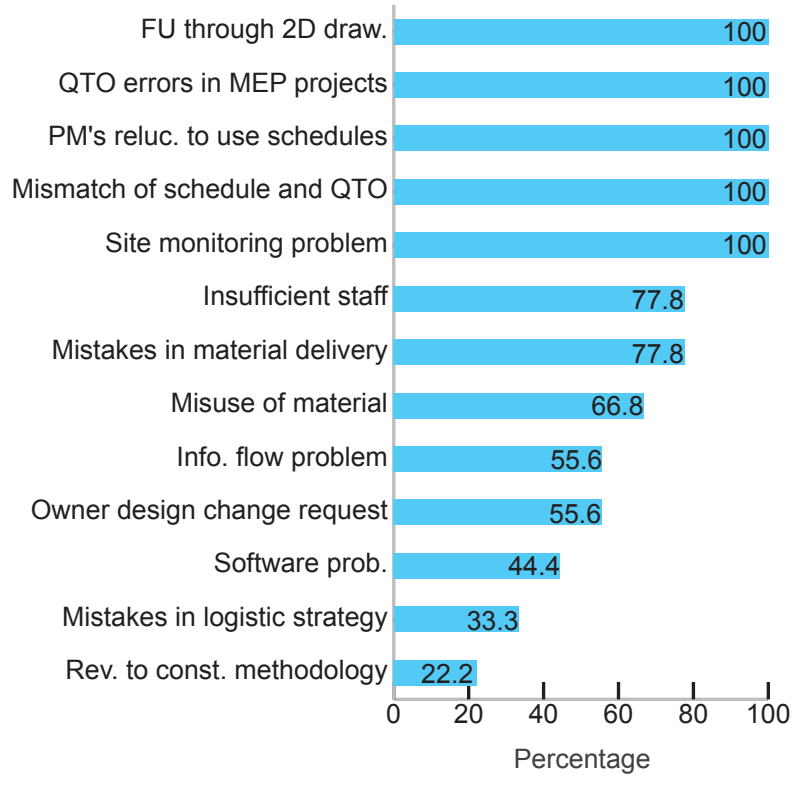

Fig. 2 Major problems that contractors suffer in planning processes term only reflects a BIM tool such as Autodesk Revit ${ }^{\circledR}$ for the contractors, not as the BIM processes. So, despite having a BIM team, they could not establish requirements and a strategy for BIM processes.

Responses to Q16 revealed that most companies use Revit $^{\circledR}(85.7 \% ; n=6)$ and follow Allplan 28.6\% $(n=2)$ as a BIM tool.

Also, in Q16, another concerning problem is shown, since most sub-contractors and suppliers do not use BIM tools, the contractors' headquarters BIM teams could not use BIM models once they prepared shop drawings and fabrication plans $(57.1 \% ; n=4)$. Therefore, although the BIM application rate of the contractors is high, they could not benefit from it sufficiently except when making presentations to the owner through the BIM model $(57.1 \%$; $=4)$.

As seen in Fig. 3, responses to Q18 showed that most contractors do not benefit from either BIM standards $(14.3 \% ; \mathrm{n}=1)$ or a BIM execution plan $(28.6 \% ; \mathrm{n}=2)$.

Fig. 3 presents the BIM structure of the interviewed contractors.

\subsection{The current level of BIM and schedule integration}

In this section, while calculating the response rate, data analysis was based on responses of 16 planning and BIM professionals, which represented a response rate of $100 \%$.

4D schedules are important tools for phasing, coordinating, and communicating planned work to various audiences (Kymmell, 2007). With the help of 4D BIM, all materials and components are predetermined. Their quantities are automatically calculated; building materials and components can be ordered electronically and delivered on-site just in time; hence, worker productivity will be increased (Ghaffarianhoseini et al., 2017). In general, productivity rate and material delivery are two critical issues,

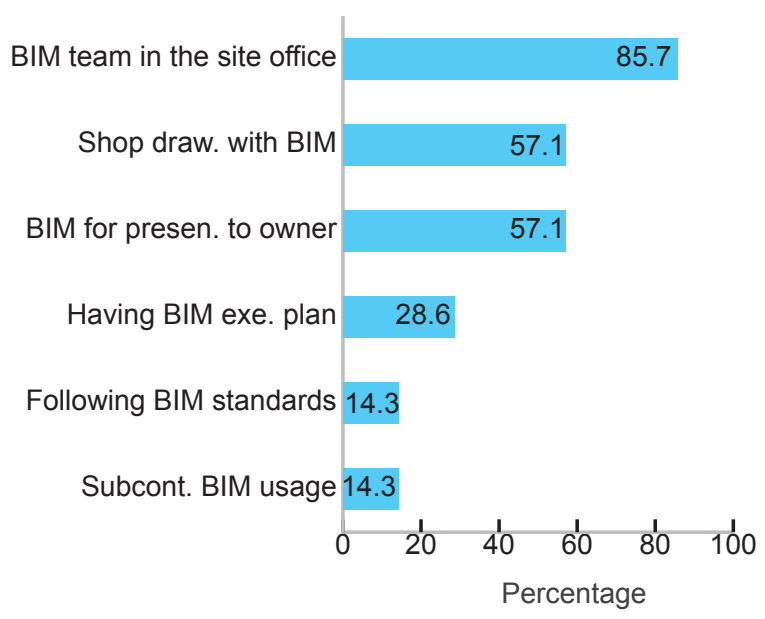

Fig. 3 BIM structure of the interviewed contractors 
primarily while contractors work abroad. So full BIM and schedule integration will be significant progress for them.

The interview revealed that the Critical Path Method (CPM) is the most used technique among respondent contractors. Responses to Q19 showed that although most contractors have BIM models, planners and project managers do not utilise the 4D BIM model while sequencing the construction activities and optimising the resources. In terms of BIM integration to the planning and control process, contractors mostly use 4D BIM for pilot studies $(43.7 \% ; n=7)$ in the early project phases. They mostly use Navisworks $(43.7 \% ; n=7)$ and Syncro $(12.5 \% ; n=2)$ as 4D BIM tools. Especially in concrete works, by using Navisworks as a BIM tool, they do not develop a 4D model in further phases. Therefore, BIM models should be organised to be used directly in the planning process.

Fig. 4 illustrates the status of BIM and schedule integration in the contractor companies. Contractors need to show more effort to achieve BIM and schedule integration for production control on site. Although BIM tools are expected to provide sufficient visualisation performances to enable effective collaboration among team members, the contractors do not benefit from these features.

\subsection{Problems encountered while implementing BIM tools}

While calculating the rate for the questions related to the BIM team structure, this section is based on the answers received from seven BIM professionals, which represented a response rate of $100 \%$.

As per the respondents, the contractor's BIM perception is only BIM tools; they do not think of BIM as a process. For example, if a contractor uses BIM tools such as Autodesk Revit ${ }^{\circledR}$, they believe they achieved BIM

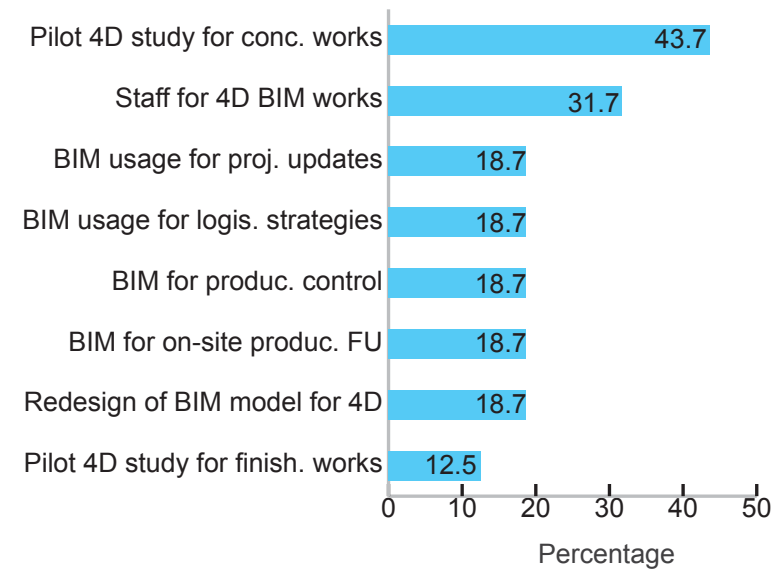

Fig. 4 The Current Level of BIM and Schedule Integration adoption. However, this belief hinders them from understanding the whole process requirements and investments. Therefore, understanding the challenges ahead in implementing BIM is the first step in finding a solution.

Responses to Q19 identified the significant following problems while implementing BIM: Technical infrastructure and server problems $(100 \% ; n=7)$; unavailable time to reach targeted LOD level $(85.71 \% ; n=6)$, high frequency change of site priorities $(85.71 \% ; n=6)$; inadequate staff for BIM model updates $(71.4 \% ; n=5)$; low rate of BIM technology usage among stakeholders $(57.1 \% ; n=4)$; Coord. Problems among stakeholders (57.1\%; n=4); Lack of BIM legal regulations $(42.8 \% ; n=3)$; High software costs $(42.8 \% ; \mathrm{n}=3)$; lack of BIM training and documentation $(28.6 \% ; n=2)$.

Fig. 5 shows the encountered challenges while using BIM tools below.

\section{Discussion}

The semi-structured interviews show that leading Turkish contractors' planning departments suffer from a lack of design documents starting from the tendering process until the construction process. Hence, contractors are missing the critical and crucial problem areas by relying on 2D drawings only, and in some cases, quantity take-off and activity sequencing problems cause project failures in terms of cost and time overruns. The schedule should be coordinated with the quantity take-off tracking. Moreover, due to the time pressure in the tender phase, contractors do not have sufficient time to create an accurate overall schedule.

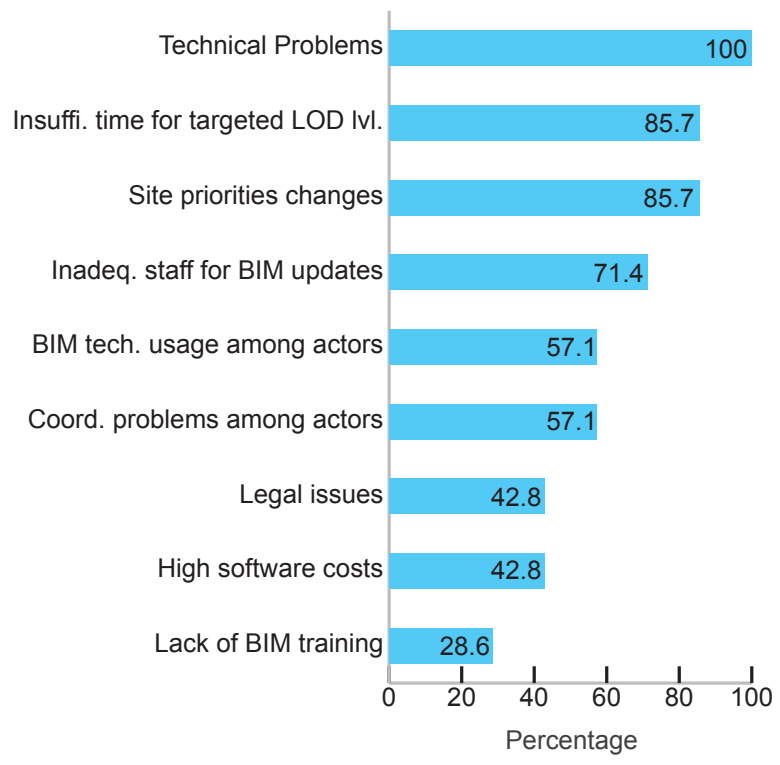

Fig. 5 Challenges while using BIM tools 
Apart from the technical aspect, another problem is that, since the project managers on site are not included in the overall scheduling process, they become unwilling to use the construction schedule efficiently in further stages. It is shown that once the project manager changes the priorities without integrating all team decisions, it results in coordination problems. Materials do not release, and projects are not approved on time. By taking the time, it becomes hard to check the projects' actual progress against what had been planned (in terms of both time and money); deviations could not be identified early. In some points, unpleasant surprises could not be avoided at the end of the project for both the company and project managers. Project managers should examine the overall construction schedule and advise accordingly if they anticipate something is wrong before the construction works start. Otherwise, project performance is being affected dramatically.

In terms of the BIM adoption process, the study revealed that, although most contractors have a BIM team in the site and central offices, they do not follow a BIM execution plan or common BIM standards. Most of them do not have a standard procedure for BIM adoption. As a result, BIM models are not enriched with the required information to be used in the planning stages, so planners do not utilise the BIM models while sequencing and optimising the construction and determining the resources. Besides, subcontractors and suppliers fall behind in terms of BIM adoption. In general, they produce the project document in 2D, which hinders producing and updating the shop drawings in 3D.

According to interviews, technical problems followed by insufficient time for targeted BIM LOD level and lack of staff are the most critical challenges when implementing BIM in Turkey. Whereas in the USA, management is monitored by legal, cultural, and financial safeguards; in the UK, cultural-related issues are followed by legal and financial aspects; in China, lack of support from senior management followed by lack of experience in adopting BIM are the most significant challenges in implementing BIM (Leśniak et al., 2021; Olanrewaju et al., 2020; Oraee et al., 2019; Sardroud et al., 2018). It seems that problems related to technical issues were primarily resolved in developed countries. In Turkey, considerable energy should be spent on technical infrastructure problems to allow working on BIM technology collaboratively. In this sense, they should first ensure that computers and networks will meet the performance requirements of any new software. Also, BIM staff should be involved in the
BIM adoption process to gain their trust and confidence in the implementation.

This study also reveals that the site team does not update the BIM models as per the current site improvements. Consequently, the BIM model does not reflect the site status, and the site team cannot use the BIM model to check the clash tests and fabrication problems before construction works start. Since scheduling the finishing works presented a more complex challenge, BIM models would be critical for production planning and construction control. Besides production control, BIM models would be helpful to follow up on the material requirement and supply. The management team needs to support the BIM team to update the BIM models, and they should prepare pilot projects to build standards for BIM applications.

As a recipe for achieving BIM and schedule integration, the leading contractors in Turkey need to build a comprehensive BIM strategy across the company. Moreover, the contractors need to be supported by government strategies in terms of BIM adaptation. BIM should be constituted as a centralised platform for coordination and communication between the design team, subcontractors, suppliers, and planners. In reality, they have the capacity and resources to achieve it. They should learn from the past experiences of developed companies in terms of BIM adaptation. They should prepare their own BIM execution plans, follow common BIM standards, and educate the BIM team and the planning team to learn how to achieve integration models. BIM models should be organised in the early phase of the project to be used directly in the planning process.

Moreover, 4D models should be issued as part of the tender package at the start of the project and should be updated accordingly. In this way, the knowledge transfer problem could be solved. This will bring them an international competitive advantage and contributes to the quality of work they perform.

\section{Conclusion}

This paper is arguably one of the pioneering studies investigating the problems encountered during planning stages and the implications of BIM and construction schedule integration in Turkish construction firms. By reviewing the current project planning practices at Turkish contractor firms, this study reveals the significant problems those contractors face and their need to apply BIM technology to contribute to the construction schedule management.

The most important conclusions drawn from this study can be summarised as follows: 
- Although that rapidly changing and up-to-date modern management tools are on the shelf, contractors use traditional methods and tools in planning and scheduling practices in general because they do not know how to incorporate modern methods and tools into their current practices. Moreover, modern methods and tools are seen only as new methods or tools rather than process improvement.

- Most planning process challenges originate from the tendering stage planning effort of construction projects. The issue is that, since the design documents are insufficient in the tendering process and incomplete for the construction process, the overall schedule usually is not created as per the project-specific information. Accordingly, there is a conflict between the overall and detailed schedules. In addition, as the overall schedule depends on personal experience and intuition, it is difficult to share the knowledge systematically throughout the project.

\section{References}

Allen, C., Smallwood, J. (2008) "Improving construction planning through 4D planning", Journal of Engineering, Design, and Technology, 6(1), pp. 7-20. https://doi.org/10.1108/17260530810863307

Arditi, D., Akan G. T., Gurdamar, S. (1985) "Reasons for delays in public projects in Turkey", Construction Management and Economics, 3(2), pp. 171-181 https://doi.org/10.1080/01446198500000013

Aredah, A. S., Baraka, M. A., Elkhafif, M. (2019) "Project Scheduling Techniques Within a Building Information Modeling (BIM) Environment: A Survey Study", IEEE Engineering Management Review, 47(2), pp. 133-143. https://doi.org/10.1109/EMR.2019.2916365

Ballard, H. G. (2000) "The Last Planner System of Production Control", PhD Thesis, The University of Birmingham.

Berg, B. L. (2004) "Qualitative Research Methods for the Social Sciences", Pearson Education, Boston, MA, USA.

Bryman, A. (2012) "Social research methods", Oxford University Press, New York, NY, USA.

Büchmann-Slorup, R., Andersson, N. (2010) "BIM Based Scheduling of Construction: A Comparative Analysis of Prevailing and BIM- Based Scheduling Processes", In: The 27th International Conference - CIB W78 Applications of IT in the AEC Industry, Cairo, Egypt, Article number: 113. [online] Available at: https://itc. scix.net/pdfs/w78-2010-113.pdf [Accessed: 24 January 2021]

Candelario-Garrido, A., García-Sanz-Calcedo, J., Rodríguez, A. M. R. (2017) "A quantitative analysis on the feasibility of 4D Planning Graphic Systems versus Conventional Systems in building projects", Sustainable Cities and Society, 35, pp. 378-384.

https://doi.org/10.1016/j.scs.2017.08.024
- The semi-structured interviews revealed that despite the contractors having BIM teams in the headquarter and site office, they could not benefit from BIM sufficiently.

- Another finding is that BIM-based scheduling (4D) BIM is used only for pilot projects as a visualisation tool, and 4D models do not address project-specific issues. In this regard, 4D models are not used as the planning tool in the project's life cycle in the contractors.

- Similar research can be carried out in different countries to compare the current planning and scheduling practices and the BIM integration level. Hopefully, this paper will help raise the awareness of BIM-based scheduling. It is worth mentioning that although the interviews were conducted in Turkey, the overall findings were obtained from competitive international contractors, so the research findings would ultimately help different contractors to improve their processes.

Churchill, G. A., Brown, T. J. (2002) "Basic Marketing Research", SouthWestern College Pub, Cincinnati, OH, USA.

Dave, B., Boddy, S., Koskela, L. (2013) "Challenges and opportunities in implementing lean and BIM on an infrastructure project", In: 21st Annual Conference of the International Group for Lean Construction (IGLC), Fortaleza, Brazil, pp. 741-750. [online] Available at: https://iglcstorage.blob.core.windows.net/ papers/attachment-58377480-00ef-401b-b904-38a4346dfd88.pdf [Accessed: 24 January 2021]

Derbe, G., Li, Y., Wu, D., Zhao, Q. (2020) "Scientometric review of construction schedule studies: trends, gaps, and potential research areas", Journal of Civil Engineering and Management, 26(4), pp. 343-363. https://doi.org/10.3846/jcem.2020.12317

Eadie, R., Browne, M., Odeyinka, H., McKeown, C., McNiff, S. (2013) "BIM implementation throughout the UK construction project lifecycle: An analysis", Automation in Construction, 36, pp. 145-151. https://doi.org/10.1016/j.autcon.2013.09.001

Easterby-Smith, M., Thorpe, R., Jackson, P. R. (2008) "Management Research", SAGE Publications Ltd., London, UK.

Engineering News-Record (ENR) (2019) "The Top 250 International Contractors", ENR, New York, NY, USA.

Faghihi, V., Nejat, A., Reinschmidt, K. F., Kang, J. H. (2015) "Automation in construction scheduling: a review of the literature", The International Journal of Advanced Manufactoring Technology, 81(9-12), pp. 1845-1856. https://doi.org/10.1007/s00170-015-7339-0

Faghihi, V., Reinschmidt, K. F., Kang, J. (2014) "Construction scheduling using Genetic Algorithm based on Building Information Model", Expert Systems with Applications, 41(16), pp. 7565-7578. https://doi.org/10.1016/j.eswa.2014.05.047 
Ghaffarianhoseini, A., Tookey, J., Ghaffarianhoseini, A., Naismith, N., Azhar, S., Efimova, O., Raahemifar, K. (2017) "Building Information Modelling (BIM) uptake: Clear benefits, understanding its implementation, risks and challenges", Renewable and Sustainable Energy Reviews, 75, pp. 1046-1053. https://doi.org/10.1016/j.rser.2016.11.083

Gledson, B. J. (2015) "Investigating the diffusion of 4D BIM innovation", In: The 31st Annual ARCOM Conference, Lincoln, UK, pp. 641-650. https://doi.org/10.13140/RG.2.1.4669.0165

Gledson, B. J., Greenwood, D. (2017) "The adoption of 4D BIM in the UK construction industry: an innovation diffusion approach", Engineering, Construction, and Architectural Management, 24(6), pp. $950-967$.

https://doi.org/10.1108/ECAM-03-2016-0066

Gong, P, Zeng, N., Ye, K., König, M. (2019) "An Empirical Study on the Acceptance of 4D BIM in EPC Projects in China", Sustainability, 11(5), Article number: 1316. https://doi.org/10.3390/su11051316

Gonzalez, V., Alarcón, L. F., Maturana, S., Mundaca, F., Bustamante, J. (2010) "Improving Planning Reliability and Project Performance Using the Reliable Commitment Model", Journal of Construction Engineering and Management, 136(10), pp. 1129-1139. https://doi.org/10.1061/(ASCE)CO.1943-7862.0000215

Gokyigit, E. (2014) "Türk İnşaat Sektöründe 4 Boyutlu (4D) Modellemenin Uygulanabilirliği" (Applicability of 4D Modeling in Turkish Construction Industry), Master's Thesis, Istanbul Teknik Üniversitesi. (in Turkish)

Han, K. K., Golparvar-Fard, M. (2015) "Appearance-based material classification for monitoring of operation-level construction progress using 4D BIM and site photologs", Automation in Construction, 53 , pp. $44-57$. https://doi.org/10.1016/j.autcon.2015.02.007

Harris, F., McCaffer, R. (2013) "Modern Construction Management", John Wiley \& Sons, Hoboken, NJ, USA.

Hartmann, T., Fischer, M. (2007) "Supporting the constructability review with 3D/4D models", Building Research \&Information, 35(1), pp. 70-80 https://doi.org/10.1080/09613210600942218

Hartmann, T., Gao, J., Fischer, M. (2008) "Areas of Application for 3D and 4D Models on Construction Projects", Journal of Construction Engineering and Management, 134(10), pp. 776-785. https://doi.org/10.1061/(ASCE)0733-9364(2008)134:10(776)

Hartmann, T., Vossebeld, N. (2013) "A semiotic framework to understand how signs in construction process simulations convey information", Advanced Engineering Informatics, 27(3), pp. 378-385. https://doi.org/10.1016/j.aei.2013.04.001

Heesom, D., Mahdjoubi, L. (2004) "Trends of 4D CAD applications for construction planning", Construction Management and Economics, 22(2), pp. 171-182. https://doi.org/10.1080/0144619042000201376

Hazır, Ö. (2015) "A review of analytical models, approaches and decision support tools in project monitoring and control", International Journal of Project Management, 33(4), pp. 808-815. https://doi.org/10.1016/j.ijproman.2014.09.005
Huber, B., Reiser, P. (2003) "The Marriage of CPM and Lean Construction", In: 11th Annual Conference of the International Group for Lean Construction, VA, USA, pp. 1-9.

Jacobs, G. F. (2010) "Review of Lean Construction Conference Proceedings and Relationship to the Toyota Production System Framework", PhD Thesis, Colorado State University.

Jongeling, R., Olofsson, T. (2007) "A method for planning of work-flow by combined use of location-based scheduling and 4D CAD", Automation in Construction, 16(2), pp. 189-198. https://doi.org/10.1016/j.autcon.2006.04.001

Kassem, M., Dawood, N., Chavada, R. (2015) "Construction workspace management within an Industry Foundation Class-Compliant 4D tool", Automation in Construction, 52, pp. 42-58. https://doi.org/10.1016/j.autcon.2015.02.008

Kazaz, A., Ulubeyli, S., Tuncbilekli, N. A. (2012) "Causes of Delays in Construction Projects in Turkey", Journal of Civil Engineering and Management, 18(3), pp. 426-435. https://doi.org/10.3846/13923730.2012.698913

Kerzner, H. (2013) "Project Management: A Systems Approach to Planning, Scheduling and Controlling", John Wiley \& Sons, Hoboken, NJ, USA.

Kim, C., Kim, B., Kim, H. (2013a) "4D CAD model updating using image processing-based construction progress monitoring", Automation in Construction, 35, pp. 44-52. https://doi.org/10.1016/j.autcon.2013.03.005

Kim, H., Anderson, K., Lee, S., Hildreth, J. (2013b) "Generating construction schedules through automatic data extraction using open BIM (building information modeling) technology", Automation in Construction, 35, pp. 285-295. https://doi.org/10.1016/j.autcon.2013.05.020

Koo, B., Fischer, M. (2000) "Feasibility Study of 4D CAD in Commercial Construction", Journal of Construction Engineering and Management, 126(4), pp. 251-260 https://doi.org/10.1061/(ASCE)0733-9364(2000)126:4(251)

Koskela, L. (2000) "An exploration towards a production theory and its application to construction", PhD Thesis, Helsinki University of Technology. [online] Available at: https://aaltodoc.aalto.fi/ bitstream/handle/123456789/2150/isbn951385566X.pdf?sequence $=1 \&$ isAllowed=y [Accessed: 24 January 2021]

Kymmell, W. (2007) "Building Information Modeling: Planning and Managing Construction Projects with 4D CAD and Simulations", McGraw Hill Professional, New York, NY, USA.

Laufer, A., Tucker, R. L., Shapira, A., Shenhar, A. J. (1994) "The multiplicity concept in construction project planning", Construction Management and Economics, 12(1), pp. 53-65. https://doi.org/10.1080/01446199400000007

Lekshmi, S. A., Unnikrishnan, V. (2018) "Planning and delay analysis of a residential complex: A case study", International Journal of Civil Engineering and Technology, 9(6), pp. 1191-1201. [online] Available at: https://iaeme.com/MasterAdmin/Journal_ uploads/IJCIET/VOLUME_9_ISSUE_9/IJCIET_09_06_135.pdf [Accessed: 24 January 2021]

Leśniak, A., Górka, M., Skrzypczak, I. (2021) "Barriers to BIM Implementation in Architecture, Construction, and Engineering Projects-The Polish Study", Energies, 14(8), Article number: 2090. https://doi.org/10.3390/en14082090 
Li, H., Chan, G., Skitmore, M., Huang, T. (2015) "A 4D automatic simulation tool for construction resource planning: a case study", Engineering, Construction and Architectural Management, 22(5), pp. 536-550. https://doi.org/10.1108/ECAM-07-2014-0093

Li, H., Huang, T., Kong, C. W., Guo, H. L., Baldwin, A., Chan, N., Wong, J. (2008) "Integrating design and construction through virtual prototyping", Automation in Construction, 17(8), pp. 915-922. https://doi.org/10.1016/j.autcon.2008.02.016

Li, H., Williams, T. (2002) "Management of complexity in enterprise integration projects by the PERA methodology", Journal of Intelligent Manufacturing, 13(6), pp. 417-427. https://doi.org/10.1023/A:1021037709972

Lu, M., Li, H. (2003) "Resource-Activity Critical-Path Method for Construction Planning", Journal of Construction Engineering and Management, 129(4), pp. 412-420. https://doi.org/10.1061/(ASCE)0733-9364(2003)129:4(412)

Mahalingam, A, Kashyap, R., Mahajan, C. (2010) "An evaluation of the applicability of 4D CAD on construction projects", Automation in Construction, 19(2), pp. 148-159. https://doi.org/10.1016/j.autcon.2009.11.015

Moon, H., Dawood, N., Kang, L. (2014) "Development of workspace conflict visualisation system using 4D object of work schedule", Advanced Engineering Informatics, 28(1), pp. 50-65. https://doi.org/10.1016/j.aei.2013.12.001

Mongalo, M. A., Lee, J. (1990) "A comparative study of methods for probabilistic project scheduling", Computers \& Industrial Engineering, 19(1-4), pp. 505-509.

https://doi.org/10.1016/0360-8352(90)90169-M

Navon, R., Sacks, R. (2007) "Assessing research issues in Automated Project Performance Control (APPC)", Automation in Construction, 16(4), pp. 474-484. https://doi.org/10.1016/j.autcon.2006.08.001

Olanrewaju, O. I., Chileshe, N., Babarinde, S. A., Sandanayake, M. (2020) "Investigating the barriers to building information modeling (BIM) implementation within the Nigerian construction industry", Engineering, Construction and Architectural Management, 27(10), pp. 2931-2958. https://doi.org/10.1108/ECAM-01-2020-0042

Olde Scholtenhuis, L. L., Hartmann, T., Dorée, A. G. (2016) "4D CAD Based Method for Supporting Coordination of Urban Subsurface Utility Projects", Automation in Construction, 62, pp. 66-77. https://doi.org/10.1016/j.autcon.2015.10.013

Oraee, M., Hosseini, M. R., Edwards, D. J., Li, H., Papadonikolaki, E., Cao, D. (2019) "Collaboration barriers in BIM-based construction networks: A conceptual model", International Journal of Project Management, 37(6), pp. 839-854. https://doi.org/10.1016/j.ijproman.2019.05.004

Pellerin, R., Perrier, N. (2019) "A review of methods, techniques and tools for project planning and control", International Journal of Production Research, 57(7), pp. 2160-2178. https://doi.org/10.1080/00207543.2018.1524168

Rapley, T. J. (2001) "The art(fulness) of open-ended interviewing: some considerations on analysing interviews", Qualitative Research, 1(3), pp. 303-323.

https://doi.org/10.1177/146879410100100303
Sacks, R., Koskela, L., Dave, B. A., Owen, R. (2010) "Interaction of Lean and Building Information Modeling in Construction", Journal of Construction Engineering and Management, 136(9), pp. 968-980. https://doi.org/10.1061/(ASCE)CO.1943-7862.0000203

Sahu, K., Sahu, M. (2014) "Cost \& Time and Also Minimum Project Duration Using Alternative Method", International Review of Applied Engineering Research, 4(5), pp. 403-412. [online] Available at: http://ripublication.com/iraer-spl/iraerv4n5spl_03. pdf [Accessed: 24 January 2021]

Sardroud, J. M., Mehdizadehtavasani, M., Khorramabadi, A., Ranjbardar, A. (2018) "Barriers Analysis to Effective Implementation of BIM in the Construction Industry", In: The 35th International Symposium on Automation and Robotics in Construction (ISARC), Berlin, Germany, pp. 64-71.

https://doi.org/10.22260/ISARC2018/0009

Sarhan, S., Fox, A. (2013) "Performance measurement in the UK construction industry and its role in supporting the application of lean construction concepts", Australasian Journal of Construction Economics and Building, 13(1), pp. 23-35. https://doi.org/10.5130/AJCEB.v13i1.3069

Succar, B. (2009) "Building information modelling framework: A research and delivery foundation for industry stakeholders", Automation in Construction, 18(3), pp. 357-375. https://doi.org/10.1016/j.autcon.2008.10.003

Tezel, A., Koskela, L., Tzortzopoulos, P. (2016) "Visual management in production management: a literature synthesis", Journal of Manufacturing Technology Management, 27(6), pp. 766-799. https://doi.org/10.1108/JMTM-08-2015-0071

Tjell, J., Bosch-Sijtsema, P. M. (2015) "Visual Management in Mid-sized Construction Design Projects", Procedia Economics and Finance, 21, pp. 193-200. https://doi.org/10.1016/S2212-5671(15)00167-7

Trebbe, M., Hartmann, T., Dorée, A. (2015) "4D CAD models to support the coordination of construction activities between contractors", Automation in Construction, 49, pp. 83-91. https://doi.org/10.1016/j.autcon.2014.10.002

Tulke, J., Hanff, J. (2007) "4D Construction Sequence Planning - New Process and Data Model", In: The 24th International Conference on Information Technology in Construction CIB-W78, Maribor, Slovenia, pp. 79-84. [online] Available at: https://itc.scix.net/pdfs/ w78-2007-012-088-Tulke.pdf [Accessed: 24 January 2021]

Turkish Contractors Association (TMB) "Turkish International Contracting Services", [online] Available at: https://www.trade. gov.tr/turkish-contracting-services/turkish-contracting-services [Accessed: 24 January 2021]

Ugur, L. O., Baykan, U. N. (2008) "Türk İnşaat Firmalarinin Proje Planlama Uygulamalari Konusunda Bir Alan Çalişmasi" (An Area Study About Project Planning Applications of Turkish Construction Firms), e-Journal of New World Sciences Academy, 3(3), Article number: A0082.

Walker, A. (2015) "Project Management in Construction", John Wiley \& Sons, Chichester, UK.

Waly, A. F., Thabet, W. Y. (2003) "A Virtual Construction Environment for preconstruction planning", Automation in Construction, 12(2), pp. 139-154.

https://doi.org/10.1016/S0926-5805(02)00047-X 
Wang, H. J., Zhang, J. P., Chau, K. W., Anson, M. (2004) "4D dynamic management for construction planning and resource utilization", Automation in Construction, 13(5), pp. 575-589. https://doi.org/10.1016/j.autcon.2004.04.003

Yin, R. K. (2009) "Case Study Research: Design and Methods", Sage Publications, Thousand Oaks, CA, USA.

Yang, J. B. (2005) "Comparison of CPM and CCS tools to construction project", In: The Third International Structural Engineering and Construction Conference (ISEC 03), Shunan, Japan, pp. 845-851.
Zhang, Z., Hamledari, H., Billington, S. L., Fischer, M. (2018) "4D Beyond Construction: Spatio-Temporal and Life-Cyclic Modeling and Visualization of Infrastructure Data", Journal of Information Technology in Construction, 23, pp. 285-304.

Zhang, H., Li, H., Tam, C. M. (2006) "Particle Swarm Optimisation for Preemptive Scheduling under Break and Resource-Constraints", Journal of Construction Engineering and Management, 132(3), pp. $259-267$.

https://doi.org/10.1061/(ASCE)0733-9364(2006)132:3(259) 